\title{
Using A Group Work Project As An Educational Tool In Management Accounting Education
}

Riaan Rudman, Stellenbosch University, South Africa Wandi Kruger, Stellenbosch University, South Africa

\begin{abstract}
Having pervasive skills is becoming more important to employers as well as to professional bodies and associations. Consequently, the ability to work in groups is regarded as an essential skill. Although working in groups is found to heighten the performance of students and lead to the development of various pervasive skills, group work still forms a very small part of most South African tertiary education teaching frameworks. As a consequence, most professional bodies have updated their competency models and syllabuses they prescribe to tertiary institutions. In response to this development, the Department of Accounting at Stellenbosch University in South Africa has developed a management accounting project requiring students to prepare a business plan for a new business venture while working in groups, giving consideration to the skills they believe they should develop. A questionnaire was created to investigate students' perceptions of group work. Responses were favourable with the majority of respondents being of the opinion that the ability to work in groups is an important skill to develop while at university before commencing their professional careers. The study highlighted some obstacles which need to be considered in developing a project requiring group work. The main constraints appear to be group selection, group size, group management and assessing group work and time.
\end{abstract}

Keywords: Accounting Education; Cooperative Learning; Group Work; Pervasive Skills

\section{INTRODUCTION}

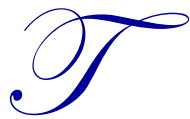

he International Federation of Accountants (IFAC) (2006, para 42) lists "working in groups effectively" as one of the key skills required in terms of the education and development programme for accounting professionals. This influences the training models of all member bodies of IFAC. Other changes have also occurred recently: advances in technology have changed the role of the accountant, auditor, and management accountant (henceforth referred to as accountant) from one of compiling financial information, which is an individual job function, to one of analysing, interpreting, and communicating information (Ballantine \& Larres, 2007). In order to do this effectively, an accountant is required to work as part of a group and to interact with co-workers and clients effectively. The working environment has also changed: collaboration is progressively becoming the norm. The reason for this is the advent of computer networks where group interaction takes place more freely. Social media has also contributed to an environment of increased collaboration amongst students (Van $\mathrm{Zyl}, 2008$ ). As a result, accounting practitioners are demanding that group work skills be developed at tertiary level before entrants enter the job market (Peek, Winking, \& Peek, 1995; Lindquist \& Abraham, 1996). The only way this can be achieved is to give students the opportunity to complete tasks and assignments in groups (Stainbank, 2003).

It is not only practitioners who have encouraged group work - educationalists have also supported the idea that teachers should encourage more student involvement in the classroom and promote cooperative learning. They should not only rely on the one-way transfer of information by the lecturer that has become the norm in accounting education (Woodbine, 1997). This requires that students participate actively in the classroom (Caldwell, Weishar, \& Glezen, 1996). By using group work as a teaching method the lecturer enhances the student's ability to acquire more 
than simply group work skills. Students may acquire other skills by presenting and discussing views through written and spoken communication (Stainbank, 2009). This promotes important intellectual and social skills which assist in preparing students for the professional working environment (Gevers \& Lubbe, 2012).

Even though there are various theoretical arguments that support the use of group work, accounting educators have not made use of group work as a teaching tool frequently because they argue that there are not many opportunities to develop these skills in tertiary institutions. The Department of Accounting at Stellenbosch University developed a group work project specifically to address these calls for change. Group work was incorporated into the management accounting project to address some of the pervasive skills required in the professional work environment. The question arises whether a tertiary institution is the appropriate place (with the necessary tools available) to allow students to develop the pervasive skills required by IFAC and employers.

The following section outlines the research objective. Section 3 presents the literature review and background of the project, followed by Section 4 which outlines the group project. Section 5 documents the research design and method. In Section 6 the results of the questionnaire are analysed, followed by a discussion on the findings, as well as an evaluation of whether a group work project addresses the skills as specified in applicable literature. The conclusion follows in Section 7.

\section{RESEARCH OBJECTIVE AND CONTRIBUTION}

There have been various calls for change within the formal training programmes of accounting at tertiary institutions. Various tools are available to lecturers to effect this change. One such tool, which is underutilised, is group work. The study reported in this article investigated the group experience. It explored the students' experiences in learning in groups and investigated which factors influenced the group participation. The primary objective of this study was to investigate students' perceptions and experience of a group work project based on the management accounting curriculum as an instrument to develop a number of pervasive skills as part of their formal studies.

This study contributes to the discussion supporting the use of group work projects to teach students pervasive skills in the field of accounting education and specifically in management accounting. It adds to the ongoing discussion about changes needed in accounting education in both a South African and an international context which has been slow to change. This study is also relevant to educators in general, because the principles and findings are applicable to group work projects in any environment. It also addresses the question whether tertiary institutions should be tasked with developing the skills perceived to be developed by group work.

The findings of the study are useful to management accounting lecturers as it highlights some of the benefits and issues that are involved in the use of group work projects as part of an accounting course with a strict, prescribed syllabus. The subject management accounting differs from other financial and accounting courses in that it has a prescribed syllabus covering two separate sections, namely cost accounting and financial management. Each section requires different learning approaches, teaching methods, and the development of different skills.

\section{LITERATURE REVIEW}

South Africa has a stringent qualification process which historically focused on instilling technical knowledge in students. Pervasive skills have become more important in recent times. Cooperative learning is one way by which to develop these skills.

\subsection{The South African Educational and Qualification Process}

\subsubsection{Qualification Process}

The process to qualify for a professional accounting qualification in South Africa takes seven years. Students must first obtain an undergraduate degree covering general business subjects and four professional subjects, namely taxation, auditing, management accounting, and financial accounting. This is followed by a 
postgraduate degree specialising in financial accounting or management accounting. The students must then enter into a learnership (also referred to as a 'training contract') during which time they obtain practical experience. During the training contract, students are required to write various professional examinations. During this period a student is not only required to obtain technical knowledge of accounting and other related subjects, but also to develop various other skills that are required by professional bodies. These include areas of pervasive skills, management decision making, as well as subject-specific knowledge.

It is necessary to discuss the various teaching methods utilised to teach the professional subjects during this process.

\subsubsection{Traditional Teaching Tools used by South African Tertiary Institutions}

At university, accounting and accounting-related subjects are traditionally taught by means of lectures where students do not actively participate in the learning process. During classes, theory is lectured, supplemented by class examples which tend to be short, covering a specific area of work, principle, or topic. Students are also given examples to complete at home. These examples are usually abstract, with little reference to real-life scenarios.

Traditionally, numerical subjects are taught by means of lectures entailing a discussion on the theory of a specific topic, followed by discussion on a theoretical business scenario and by working through an example, which often requires some form of calculation to be performed. The example is usually worked out by using a calculator and writing down the answer on paper. Students are rarely required to perform computer work and modelling; they only need to refer to their textbook to assist them in performing the calculation and to explain theory. Reference to external sources of information to perform the calculation is not necessary.

Attendance of lectures is not monitored and students are able to study the work from their textbooks. Assessment takes a similar format, with students being tested on theory rather than practical application. A test typically consists of a couple of brief questions, covering multiple areas of work with a specific answer.

\subsection{Expectation Gap}

Although emphasis should be placed on learning-while-doing, there is no indication in the existing accounting curriculum that provision is made for opportunities for students to experience the real world of the accounting profession (Pescow, 1963; Dombrowski, 1993). Dombrowski (1993), Gloeck and De Jager (2000), Hassall, Joyce, Arquero, and Anes (2003), and Jackling and De Lange (2009) conclude that a gap exists between the skill set employers require from their future employees and the skill set exhibited by their new employees. Coetzee and Oberholzer (2009) found the performance of entry-level accountants to be unsatisfactory to their employers, despite the fact that they were satisfied with their level of theoretical knowledge. The skills gap, depicted in Figure 1 , arises because the three levels of knowledge required by the accounting syllabus are different from that expected by potential employers. 


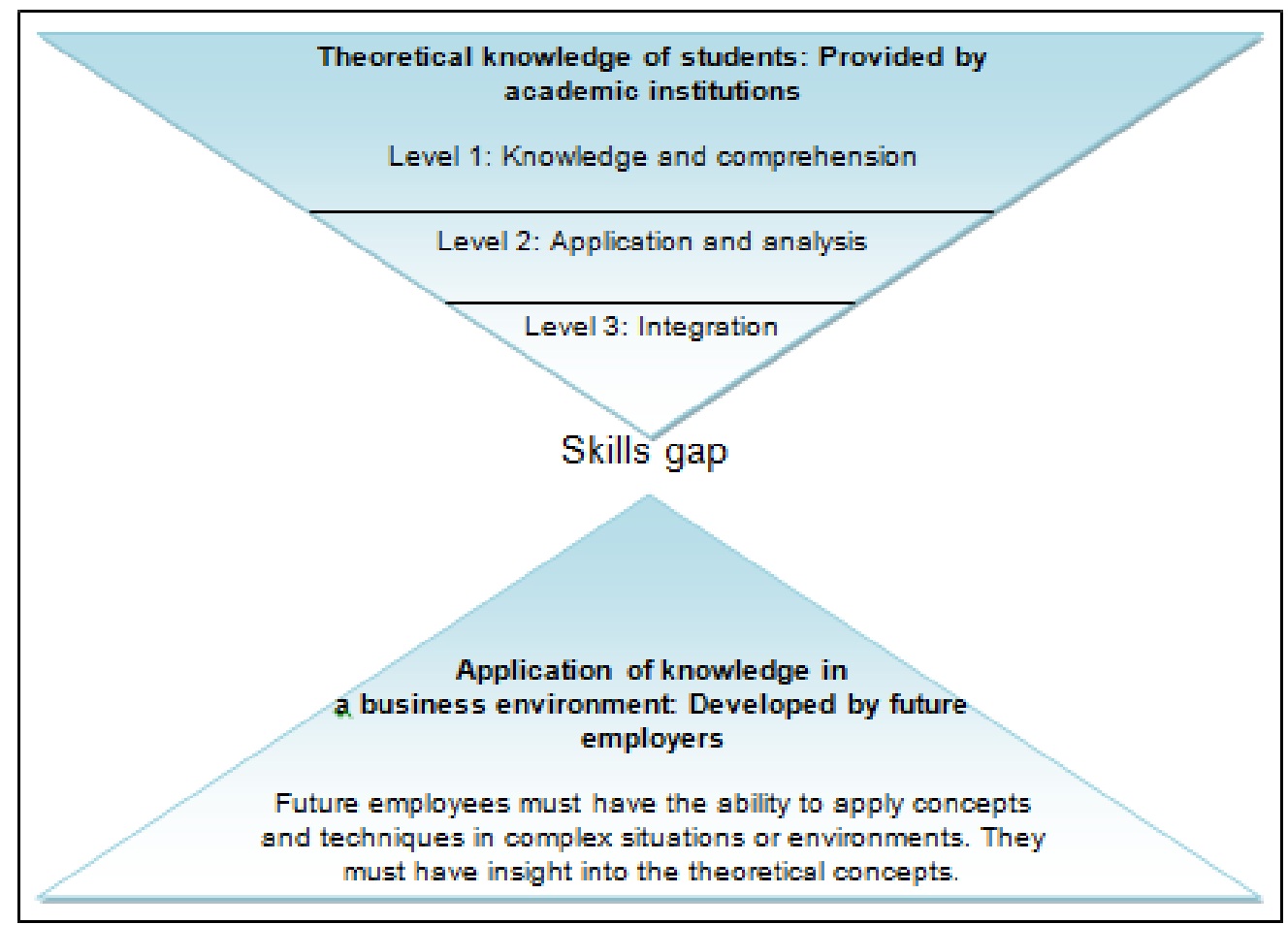

Figure 1: The Expectation Gap between Possession of Theoretical Knowledge and the Practical Application Thereof (Rudman \& Terblanche, 2012)

Dombrowski (1993) reports on the different perspectives of employers and educational providers. Auditing firms seek to recruit students who are able to apply theoretical knowledge and who have some depth of insight into theoretical concepts, while educators believe that students should learn this application of theory once they are employed in an audit practice and, therefore, focus solely on theory. He argues that if students are granted the opportunity to experience the real world of auditing while they are studying the theory, this will embed their knowledge and create an understanding of the theory which will result in a greater transfer of real-world, practical skills, rather than experiencing their undergraduate years as a series of memorising exercises.

Various studies address the specific skills deficiency of auditing graduates. Barac (2009) reports on the omissions and deficiencies identified by employers in the South African Institute of Chartered Accountants (SAICA) syllabus. These omissions and deficiencies range from general bookkeeping to public sector knowledge, summarised by a lack of practical exposure, manifesting, for example, as an inability to complete a taxation return. Furthermore, the employers reported that there is a lack of focus on the preparation of working papers and of insight into statutory matters. Vasarhelyi, Teeter, and Krahel (2010) reported on the new employees' lack of contextual knowledge that the auditor in the modern business era needs to possess, such as insight into changes within the information technology environment. These findings indicate that exposure to the business world and practical skills are relevant within the academic environment, and that it might help to bridge the gap that currently exists between academia and practice. In order to bridge the skills gap the respondents in the study by Coetzee and Oberholzer (2009) suggested that exposure to work experience should be integrated within academic programmes. For this to be possible, a stronger relationship will need to be developed between education providers and training providers and employers. This will take time. Gramling, Schatzberg, and Wallace (1996), KPMG (2009), Newcastle University (2009), and PricewaterhouseCoopers (PWC) (2009) suggested that the gap between theoretical knowledge and the application thereof can be bridged by changing the training model and the manner in which theoretical knowledge is taught. This is supported by the emerging practice of work-integrated learning. However, in order to achieve this goal, there must be calls for change in the accounting curriculum, as well as the changes to be recommended by professional accounting bodies world-wide. 


\subsection{Reaction to the Expectation Gap}

Globally, IFAC has taken the lead in developing an educational framework for the modern era. Because IFAC (2006, par 42) lists "working in groups effectively" as one of the key skills required from education and development programmes for all IFAC member bodies, the relevant institutions changed their training models. Against this background, SAICA developed a competency framework that describes the knowledge, skills, and attributes that a South African Chartered Accountant $(\mathrm{CA}(\mathrm{SA}))$ should demonstrate at the entry point to the profession (SAICA, 2010). SAICA is not the only professional organisation that investigated a new training framework. The Chartered Institute of Management Accountants (CIMA) (2010) and the South African Institute of Professional Accountants (SAIPA) have also made significant changes to their curriculum. Greater focus is placed on skills development in the areas of pervasive skills (divided into business ethics and professionalism, management and leadership (professional skills), and personal attributes), management decision making, and subject-specific knowledge. SAICA (2010) requires that students should be exposed to a number of competencies, some of which are compulsory. The listed compulsory competencies refer to continual competencies or pervasive skills and accounting and external reporting (SAICA, 2010). Various tools are available to develop these skills, and simulation in a group context has been found to be the best tool available to address pervasive skills. The SAICA (2010) competency framework specifically includes the following pervasive skills relating to group work:

Students should:

- $\quad$ apply management techniques, such as developing milestones, managing resources, and meeting deadlines;

- $\quad$ lead effective meetings;

- $\quad$ respect deadlines, manage time, and organise tasks logically;

- $\quad$ delegate tasks effectively;

- $\quad$ manage and supervise others effectively;

- $\quad$ work effectively with colleagues from diverse backgrounds and cultures;

- $\quad$ collaborate with colleagues and work effectively as group members;

- $\quad$ resolve conflict and negotiate appropriate solutions; and

- $\quad$ communicate effectively in verbal format.

Note that the other continual competencies and the accounting and external reporting requirement fall outside the scope of this article and form the basis of other research.

\subsection{Cooperative Learning}

The skills discussed in Section 3.3 cannot be developed in traditional accounting lectures, but group work can be used to fill this gap by having students work together towards a common goal.

\subsubsection{Defining Cooperative Learning}

Group work and cooperative learning as educational tools have seen some growth in utilisation in the past couple of years in various subject areas and have been used in the sciences for some time. Cooperative learning can be defined as students learning or working in groups (Stainbank, 2003). A learning group "usually consists of three to five students who work together for short or extended periods of time on problems, interpreting lecture material, or other assignments" (Sullivan, 1996, p. 108).

\subsubsection{Need for Cooperative Learning}

Due to changes within organisations over the last few years (Gevers \& Lubbe, 2012), companies have also moved towards group work (Ambrose \& Kulik, 1999) and for that reason group-based skills are essential for accountants to be effective in the workplace (Ramsay, Hanlon, \& Smith, 2000). According to O'Conner and Yballe (2007) group work can assist them in learning critical skills valued by prospective employers. Turning to group structures is a way to share, capture, and deploy the knowledge needed to give the organisation competitive 
advantage (Kennedy, 2000). It is important to remember that work conducted by the accounting profession is often conducted in groups, in contrast with the approach used when teaching many subjects at university where mostly all projects are conducted by students individually.

Gevers and Lubbe (2012) ask why there should be an increase in focus on group work and cooperative learning within higher education. One possible reason is that students today are raised in a fundamentally different way than students were raised 20 years ago. Today's students' lives are influenced by television, the internet, and technology, with the result that much of their time is spent on individual pursuits. However, this in contrast with the situation 20 years ago where learners spent their afternoons playing outside and participating in sports that promote group work skills. These skills must now either be developed at work or by tertiary institutions within the classroom.

Another contributing factor is changes in the landscape of higher education. Student numbers have increased without a corresponding increase in lecturers. The large lecture format does not support active learning in the same way as group work does (Gevers \& Lubbe, 2012) since it is largely passive lessoning.

As the focus of the Department of Accounting is to educate future CA(SA) and management accountants (CIMA), it is necessary to expose students to working in groups. For this reason, students keep higher education institutions accountable for best preparing them for future employment. Therefore, it is evident that including group work in the curriculum will better equip students for their future careers (Gevers \& Lubbe, 2012).

Cooperative learning requires a paradigm shift from a teacher-focused method to student and learner development (Rassuli \& Manzer, 2005). This creates a greater need for active student involvement in the classroom (Johnson, Johnson, \& Smith, 1992). By involving students in the learning process, the role of the lecturer changes from that of a teacher to a facilitator for learning (Rassuli \& Manzer, 2005).

Studies investigating business groups suggest that successful groups require goal clarity and measures to encourage group work (Kaplan \& Norton, 1992). This view is supported by Kennedy (2000) who emphasises that for a group to be effective, the right conditions also need to be in place.

The main goal of cooperative learning is to maximise all group members' learning efficiency (Hwang, Hwang, \& Tsai, 2008). O’Conner and Yballe (2007) suggest five individual goals that group work should have:

- $\quad$ All group members should have an overall positive experience.

- $\quad$ Students should learn about groups and group dynamics.

- $\quad$ Students should also learn more about themselves and leadership.

- $\quad$ Students should develop both interpersonal skills and group competencies.

- Students should learn about the content of the task they were given to perform.

Cottell and Millis (1993) are of the opinion that five features are necessary to ensure a successful grouplearning experience. These features are briefly explained below (see Caldwell, Weishar, \& Glezen, 1996).

- $\quad$ Student interdependence is established by structuring the group task in such a way that students have identical learning objectives.

- Individual accountability discourages certain students in the group to sit back and let the other students complete the task.

- $\quad$ Appropriate grouping is established when heterogeneous groups are formed. Heterogeneous groups consist of group members from sexes, different learning abilities, and ethnic diversity.

- $\quad$ Social skill interaction entails proper communication, building trust, and providing leadership and it manages conflict among group members. If students have not had previous experience of cooperative learning, they must be taught these behaviours and encouraged to use them.

- Group monitoring ensures that the group members of the group are working effectively together and that changes are made to the group if necessary.

If these objectives are not addressed the result may be ineffective groups and unproductive learning. 


\subsubsection{Benefits and Constraints of Cooperative Learning}

There are many benefits associated with cooperative learning, such as improved student involvement in the learning process (Ramsay et al., 2000), building group skills, improving communication skills, and allowing students to develop "relationships with common objectives in mind" (Woodbine, 1997, p. 2). Other benefits that may be derived include positive self-esteem and building of interpersonal skills (Lindquist \& Abraham, 1996). Sullivan (1996, p. 107) adds that cooperative learning "emphasises the development of critical thinking via discussion, debate and group work." Furthermore, students may feel secure within the psychological safety of the group (Edmondson, Bohmer, \& Pisano, 2001) of cooperative group mates, and a deeper level of thinking can take place (Knabb, 2000). Knabb (2000) adds that students will learn more and in greater depth when they share information and help each other. It is clear from the above that cooperative learning can be useful in teaching students a number of skills which are not developed in the current model.

A study conducted by Gevers and Lubbe (2012) indicated that students (in general) have a positive perception of group work. A study conducted by Berry (cited in Ballantine \& Larres, 2007) reported that the use of group work in developing students' group work skills was also successful.

However, some authors are of the opinion that cooperative learning may have a negative influence on students in that it affects the students' study time (Holt, Michael, \& Godfrey, 1997). Other problems that might arise include conflicting personal agendas of group members (Ohl \& Cates, 2006), different expectations or perceptions about the assessment requirements of the task (Anderson, 2005), and the logistics of coordinating timetables and workloads (Lou, Abrami, Spence, Poulsen, Chambers, \& D’Apollonia, 1996).

\subsection{Aspects to Consider When Developing a Group Work Project}

Although cooperative learning has the potential to be used as an effective learning tool, there might be a number of considerations that should be taken into account when developing a group work project. These are briefly discussed below.

\subsubsection{Group Selection}

A number of methods exist according to which group members can be selected. For instance, students may assign themselves to groups, be randomly assigned, or they be assigned by the lecturer (Lou et al., 1996). The implication of students assigning themselves to groups is that less conflict is likely to arise in the group, but the group might not be as diverse and dynamic as when a lecturer assigns the students. A research study by Smith and Spindle (2007) on cooperative learning investigated the effect of group composition on individual student performance and concluded that students rate cooperative learning more highly than completing individual assessments and that students prefer selecting their own groups as opposed to groups selected by the lecturer.

\subsubsection{Group Size}

The size of a group can have a significant impact on the effectiveness of the group. The larger the group, the harder members may find it to identify with other group members. They may struggle to coordinate their schedules so as to meet for the projects because they may have different time tables.

\subsubsection{Group Management}

Groups need to be managed effectively, otherwise dysfunctional groups may emerge which may result in "a learning environment that is inferior to that of individualistic learning" (Ballantine \& Larres, 2007, p. 166). Various recommendations have been put forward to ensure effective group functioning: The lecturer should act as a facilitator to assist students in developing the group skills that are essential to deal with the problematical nature of cooperative work; groups of two to four members should work effectively if the lecturer sets out clear guidelines at the beginning of the project for effective group functioning; each group should select a group member who accepted leadership of the project at the beginning of the project and the lecturer should emphasise the leader's role throughout the project. 


\subsubsection{Assessing Group Work}

The adoption of group grading can be experienced as either positive or negative by students. The students' experience will be affected by whether members contribute equally or not to the group. Ballantine and Larres (2007) found that if all group members contribute equally to the project, group grading is perceived positively and fairly by group members. However, if one or more students do not do their fair share of work (that is, if they are nonperforming group members who reap the benefits of the outcome of the project), the other members may often also get demotivated and discouraged to contribute fully to the project, causing them to achieve lower marks than which they were able to attain if the proper group dynamics were in place.

\section{BACKGROUND TO THE MANAGEMENT ACCOUNTING PROJECT}

Since the School of Accountancy at Stellenbosch University is educating future professional accountants, the department is obliged to present a course which ensures that the skills set out by the professional bodies are developed in students (refer to Section 3.3). In an effort to do this a management accounting project in which students are required to prepare a business plan, using their management accounting knowledge and IT skills in a group format was developed.

The management accounting project differed from traditional management accounting teaching methods in that students were required to consult external sources and conduct in-depth research in order to compile a business plan. The project gave students insight into the workings of management accounting and basic strategic thinking. The project consisted of a management accounting project and business plan in which the students were required to prepare a strategic business plan for a new business. It included market research, selecting strategies as well as financial information in the form of budgeted figures for five years.

The purpose of the project and background to the project was explained to students. The students were first given information about a hypothetical wine company for which they were required to prepare a model to assist them in preparing the budgeted information for the strategic business plan of the company. Students were taught various formulas and techniques, by means of class discussion, which could be used to prepare the models they were taught. Aspects relating to effective group work, group selection, and project management, amongst other things, were also discussed.

They were then required to prepare a business plan for a hypothetical company of their choice. The business plan covered the two major areas: The students were required to document, amongst other things, background information on the business as well as information on financing options and possible strategies and legal entities, and to prepare budgeted financial information for five years, using management accounting principles. The students also completed two electronic tests, which required them to use IT techniques and management accounting knowledge to perform business modelling. The final examination tested the student's knowledge developed during the project.

While the project was being developed, the outcomes were aligned with the academic requirements set out by SAICA. The SAICA syllabus was used because it best resembles the IFAC requirements and is considered to be comprehensive. The project was aimed at teaching students both sets of compulsory requirements. Some of the outcomes of the project included operating in a group situation, time management skills, problem-solving skills, oral communication skills, conceptual thinking skills, and applying theory in a practical scenario.

In order to address the issues identified in Section 3.5 the following approach was adopted:

- $\quad$ Group selection: A self-selection approach was used because it was expected that students would be more willing to participate and contribute toward the outcome of the project (especially introverted students) if the environment in which the group operated was relatively familiar. Furthermore, students had not been exposed to group work before.

- $\quad$ Group size: Students could determine their own group size of between two and four members as suggested by Gevers and Lubbe (2012). 
- $\quad$ Group management: The lecturer set out clear guidelines at the beginning of the project for effective group functioning. This included a discussion on the effective functioning of the groups. Each group had to select a group member who accepted responsibility for leading the group. The lecturer also emphasised this aspect throughout the project.

- $\quad$ Assessment of work: The group was awarded a single mark. Requiring students to individually hand in a separate document for the group project would defy the purpose of the project.

\section{RESEARCH DESIGN AND METHOD}

\subsection{Overall Research Design and Method}

A review of available South African and international literature was undertaken to identify recent research on the subject of group work in general and specifically on group work that was used in a project context. Considerations were also given to group work used in business and accounting related subjects. Thereafter a questionnaire was developed to obtain the students' opinions of their experiences while working in a group. The questionnaire contained questions covering the students' demographic and biographical information and their perceptions and experiences during the group work project. The questionnaire was reviewed by two management accounting lecturers, four information systems lecturers, a statistician, and a sample of potential respondents in order to evaluate the validity, unbiased nature and completeness thereof. After each stage of review; the questionnaire was amended to take the reviewers' comments into account. In order to avoid bias in the replies from respondents, an effort was made to distribute potentially related questions throughout the questionnaire. Open-ended questions were also included throughout the questionnaire to support findings from questions that placed reliance on a Likert-scale. The questionnaire is available from the authors on request.

The questionnaire was made available on an electronic platform to 324 management accounting students who took part in the project. All of these students were registered for a second-year information systems course, as well as a second-year management accounting course. Completion of the questionnaire was voluntary, and students were assured that their responses would be dealt with anonymously and would not have an influence on their marks, in order to avoid bias. One hundred and sixteen useful responses were obtained. After the responses had been received, the data was cleaned by removing instances where students clearly did not attempt to answer the questionnaire or instances of incomplete information. The results were analysed in $M S$ Excel $^{T M}$ in order to draw conclusions on students' perceptions of group work. Cluster analysis was performed for analysing the answers to the open-ended questions and the answers were summarised in similar categories.

\subsection{Limitations of the Study}

Undergraduate students at South African universities are traditionally not frequently exposed to real-life scenarios. Questions relating to students' perceptions of the usefulness of a real-life scenario (in the form of a management accounting group project) were also included as part of the questionnaire. These questions relating to the skills developed using a real-life scenario fall outside the scope of this article. It is noteworthy that in these questions the students were asked to rate the skills in the order in which the project developed the various skills the most. The highest percentage awarded was for group work. The second component of the questionnaire formed the basis of the research.

There were also other limitations to this study. The questionnaire tested students' experience and perceptions of group work and not the actual benefit derived. Furthermore, it can be argued that factors such as student marks could have had an impact on the students' perceptions. Information related to gender and academic performance was not analysed due to ethical limitations imposed regarding the nature of questions which may be asked from human subjects in South Africa.

\section{EMPIRICAL RESEARCH FINDINGS}

The findings focus on the students' willingness to participate, the benefits and constraints of taking part in a group project and whether the group project addressed the appropriate skills. 


\subsection{Willingness to Participate}

From the total population of 324 students, 116 useful responses were obtained, giving a response rate of $35.8 \%$, which was regarded as a representative sample in light of the exploratory nature of this study. The majority (96.6\%) of the respondents stated that they believed working in groups is an important skill to develop at university and that it would assist them in their future careers. Of the respondents, 53.4\% indicated that had not had any previous exposure to activities which required their participation in a group. Until the time that the students took part in the group project, none of their courses included group work elements. The only opportunity students had to take part in group work (not related to social activities) was either in their residences (i.e., outside class) or in a work environment (if they previously did vacation work) and not in an academic environment. This also indicates that students did not actively seek opportunities to engage in groups before the project and therefore they were not required to work in groups until then. If the premise is that group work is important to future success, then this lack of exposure to group work supports the motivation of professional bodies to require universities to include teaching tools in the curriculum that enhance pervasive skills developed by group work. This might be because professional bodies may realise that students who did not have the experience of working in groups will lack the necessary pervasive skills in future.

It is generally accepted that most accounting students prefer passive learning. Many accounting lecturers struggle to get students to participate in during lectures. After the project, $44.8 \%$ of the respondents indicated that the project had encouraged them to participate in seminars, lectures, and tutorial discussions. A similar percentage of respondents also stated that they would be more likely to participate during lectures in future, possibly because they had greater self-confidence and felt more comfortable about expressing their ideas than before being exposed to the project.

\subsection{Obstacles to Group Work}

There are four documented obstacles (refer to Section 3.5) to group work. The following section presents the opinions of students on these obstacles.

\subsubsection{Group Selection Method}

It was evident that $89.7 \%$ of respondents prefer peer- or own-group selection when group work is conducted. Furthermore, $86.2 \%$ of the respondents indicated that their groups consisted of students with whom they normally study, go to classes, and socialise. This indicates that students do not like to work outside their 'comfort zone.' This highlights two issues in the real world. Employees cannot select their own groups; they may be forced to work with people they might otherwise not necessarily have associated with. Secondly, if students work with their friends, one may ask whether they are actually learning new communication skills or gaining the ability to interact with people they would not normally associate with. Moreover, it could be argued that they do not develop the skill to select a group or to select their own group members in order to form groups that achieve the best outcome, or to evaluate students' skill levels and to identify the skills required to complete a project. This will be addressed in future courses.

The remainder of the respondents (13.8\%) preferred groups to be assigned by the lecturer. At the start of the project the lecturers received a number of requests from students to be assigned to a group by the lecturer. These requests were from students who were either repeating the course (without any friends in the class) or students who had changed from one course to the other.

\subsubsection{Group Size}

Much research has been conducted on the optimal group size. The results in Table 1 reflect a pattern that is similar to the one found in the research conducted by Gevers and Lubbe (2012). 
Table 1: Group Size

\begin{tabular}{|l|c|}
\hline \multicolumn{1}{|c|}{ Group Size } & Percentage of Total Respondents \\
\hline 1 to 2 group members & $3.4 \%$ \\
\hline 2 to 3 group members & $25.0 \%$ \\
\hline 3 to 4 group members & $61.2 \%$ \\
\hline 4 to 5 group members & $8.6 \%$ \\
\hline More than 5 group members & $1.7 \%$ \\
\hline
\end{tabular}

It can be argued the more students in the group, the less work there is to do by each group member; however, the respondents did not agree. The majority $(82.8 \%)$ of respondents preferred smaller group sizes. Very few students were willing to work alone. Based on initial enquiries by students, it appeared that students would rather work with strangers than alone. This is attributed to students not wanting to work alone; wanting to reduce the workload, and considering having multiple opinions on a topic to have value.

\subsubsection{Group Management}

As noted, in order to ensure proper group management, each group was instructed to select a group member to accept leadership responsibilities of the project. However, regardless of this instruction, students managed the group using various methods, including autocratic or democratic management styles. Each method requires a leader to provide direction and followers to perform tasks. The level of participation needs to be balanced. How the leader determined the direction of the group and make decisions varied, as shown in Table 2.

Table 2: Group Management

\begin{tabular}{|l|c|}
\hline \multicolumn{1}{|c|}{ The Groups } & Percentage of Total Respondents \\
\hline Leadership & $81.1 \%$ \\
\hline Selected a group member to fulfil a leadership role in the group. & $83.7 \%$ \\
\hline Delegation & $92.3 \%$ \\
\hline Looked at the members' ability when allocating work. & $75.0 \%$ \\
\hline Properly planned and delegated work according to the group plan. & $91.4 \%$ \\
\hline First researched then discussed and delegated the work. & \\
\hline $\begin{array}{l}\text { Found the most efficient method was to delegate work and only discuss it after the } \\
\text { work was performed by a particular group member. }\end{array}$ & $94.0 \%$ \\
\hline Discussion & $89.7 \%$ \\
\hline Members listened to every group member's views and opinions. & \\
\hline $\begin{array}{l}\text { Discussed important decisions and those relating to the project before making a final } \\
\text { decision. }\end{array}$ & \\
\hline Support & \\
\hline $\begin{array}{l}\text { Indicated that group members were willing to assist other members in all aspects of } \\
\text { the project although it might not be the section of the project researched by them. }\end{array}$ & $89.7 \%$ \\
\hline
\end{tabular}

The response rates were high and mimic the perfect group interaction scenario in terms of leadership, delegation, discussions around sections of the project and support and providing assistance to each other. Whether all these parameters were applicable is uncertain and might prove to be inefficient. There were inefficiencies in the manner in which work was delegated to group members. The open-ended questions confirmed that the students preferred to delegate work to a particular person who was then required to perform the work and conduct the research. His/her findings were then discussed among the members in the group. This is an inefficient way to work, because the discussions were held with uninformed members. On the other hand, because no member of the group was considered to be an expert, a better result and output would have been obtained had everyone researched all aspects relating to the project. The findings were consolidated and discussed and only then the work was delegated to a particular member of the group to write up. Respondents also learned the importance of proper planning and delegation of work among group members. This would be a valuable asset for the respondents in their future jobs.

It was inevitable that conflict would arise. The points of conflict therefore needed to be addressed. Students were able to resolve conflicts and differences of opinion in the group without any intervention from the lecturer (90.4\% of respondents). This can be ascribed to the fact that most respondents indicated that the group's composition consisted of students the group members usually worked with. 
Most groups recognised the fact that each group member has different abilities ( $81 \%$ of respondents). Groups identified each group member's strengths and allocated the work according to these abilities. This was done via discussion in the group and in most cases driven by the students stated strengths and weaknesses or their preference for the work being delegated. By conducting this exercise the group could use each member's strengths to the advantage of the group as a whole. This is a positive sign and shows that most groups operated effectively. When groups operate effectively it is an indication that a number of the skills required by professional bodies is starting to develop in students.

It can also be deduced (see Table 2) that respondents learned how to listen, collaborate, and share ideas with each other. This teaches group members that there is more than one method of conducting a project and there is not necessarily only one correct answer to a problem. This exchange of ideas would not previously have occurred in normal lectures where students are passive learners.

\subsubsection{Assessing Group Work}

The group project was assessed as a whole and not accordingly to individual sections prepared by the individual group members. At the beginning of the project the lecturer emphasised that the group members were responsible to ensure that each group member contributes equally to the project as a single mark will be allocated to all students in the group. Interestingly, 59.5\% of respondents were of the opinion that they would have received a much lower mark had they completed the project on their own. This can be attributed to the collaborative nature of the project requiring students to obtain multiple views, discuss ideas, and consequently select a course of action (see Section 6.2.3). The students stated that this approach allowed students to identify errors in sections of work completed by a specific team member.

It can be inferred that students would also learn a great deal from fellow students (see Table 3). Discussion about the project continued outside of the group context $(75 \%)$.

Table 3: Learning Experience from Other Group Members

\begin{tabular}{|l|c|}
\hline \multicolumn{1}{|c|}{ Learning Experience } & Percentage of Total Respondents \\
\hline Other group members learn from me. & $82.8 \%$ \\
\hline I did learn something from other group members. & $90.5 \%$ \\
\hline I contributed to the group in meaningful way. & $97.4 \%$ \\
\hline
\end{tabular}

The downside of allocating a single mark is that some respondents might receive a higher mark without making any contribution to the group or project. Of the respondents, $22.4 \%$ indicated that not all group members contributed equally to the project. This low percentage could be attributed to the belief held by the respondents $(75 \%)$ that everyone had a vested interest in the project. Similarly, $31.9 \%$ of respondents answered that they had to conduct most of the group work in their group. This is a relatively low percentage and accounts for the differences in responses in Section 6.2.3. Various reasons might exist for students to hold this belief. It might be an indication of a dominant personality with which other group members' personalities clashed and which might have led to withdrawal from the project by introverted group members and vice versa. This could also be true for students who indicated that they would have wanted to conduct the work on their own. Furthermore, this is an indication of potential improper group management.

Respondents were asked whether cultural differences caused any barriers or issues during the group work project. A majority of respondents indicated that cultural issues had no effect on how effectively the group operated. This is a very positive sign. The respondents grew up in the post-apartheid era (after 1994).

\subsection{Constraints Arising from the Group Work}

Overall, the students received the project favourably, with many students supporting the view that group work projects should be used as a teaching tool. However, there was still some resistance towards group work and a number of respondents preferred working on their own. This was, for a large portion (42.2\%) of the respondents, their first exposure to group work. It is expected that as students become more exposed to group work projects their resistance to group work might diminish. 
This result makes it even more imperative for lecturers to integrate group work projects in the accounting curriculum in order to increase the students' willingness to participate in a group. Experiential learning should become the norm.

One of the most significant constraints or disadvantages arising from the group work project listed by $61.2 \%$ of the respondents was that the time taken to complete the project could have been spent on studying. Prior research on experiential learning tools has also highlighted this as the most important issue. The other constraints relate to logistics and entailed project-specific feedback.

\subsection{Usefulness of a Group Work Project for Teaching Pervasive Skills}

Eighty-eight percent of the respondents believed that the project will assist them in their future jobs; $64.7 \%$ of the respondents indicated that they look forward to working in groups once employed and $88.8 \%$ of the respondents were of the opinion that they had learned non-academic skills, specifically group work skills from the project that they would not have learnt in a traditional class situation under the current teaching model. This shows the importance of integrating pervasive skills into projects because knowledge can be transferred to students in a lecture room situation, but not pervasive skills.

The questionnaire contained a variety of questions to gauge students' perceptions of various potential benefits of the management accounting group work project. In addition to these questions, respondents were asked to list the top three benefits arising from the group project. The number one benefit students highlighted was learning skills to operate in a group situation. Table 4 confirms that one of the objectives of the project, which was teaching students pervasive skills specifically in a group context, was achieved. The results of the top perceived benefits/skills acquired indicated by students are summarised in Table 4 .

Table 4: Non-Academic Skills

\begin{tabular}{|l|c|}
\hline & Percentage of Total Respondents \\
\hline Learning new social interaction skills & $92.2 \%$ \\
\hline Learning to motivate other students & $87.1 \%$ \\
\hline Learning to coach other students & $75.9 \%$ \\
\hline
\end{tabular}

It is a positive result that students ranked social interaction skills highly, as most accounting courses are 'individual' courses where students are required to complete most of the tasks on their own. It was shown that $80.2 \%$ of the students took their group member's circumstances into account during the project and $97.4 \%$ of respondents did not view cultural differences as a problem. In the class the biggest cultural difference appeared to arise due to language. Race did not affect the majority of the groups, as noted in Section 6.2.4. It is interesting to note that respondents indicated that they developed skills like motivation and coaching which currently are not specifically included in the accounting curriculum. This indicates that a group work project sets the scene for teaching students additional skills which cannot be taught through individual tasks.

Many have argued that the way for students to acquire pervasive skills is by practising the skills through creating an environment that simulates real life in or outside the classroom. Many of the respondents stated that they continued discussions after class because of the group nature of the project. Students were encouraged during lectures to discuss the project amongst themselves, as well as with other students who were not necessarily part of the group; however, only $12.9 \%$ of the students indicated that they had consulted other students in other groups.

\subsection{Appropriateness of a Group Work Project}

The last question was intended to determine whether the group work project achieved the objectives outlined in prior literature. Literature discussed in Sections 3.3 and 3.5 highlighted criteria which must be met for group work projects to be effective in developing pervasive skills. Table 5 summarises the findings of this study, showing that group work is an appropriate teaching tool to instil the skills required by the accounting profession and employers by listing the criteria which was identified by literature (Cottell \& Millis, 1993; O'Conner \& Yballe, 2007; SAICA, 2010) which much be present before a cooperative learning project is able to effectively develop pervasive skills. 
Table 5: Appropriateness of Group Work Projects to Develop Pervasive Skills

\begin{tabular}{|c|c|c|c|}
\hline Criteria & Comment & $\begin{array}{c}\text { Objective } \\
\text { Achieved by } \\
\text { Group Work } \\
\text { Project } \\
\end{array}$ & $\begin{array}{c}\text { Section } \\
\text { Reference }\end{array}$ \\
\hline \multicolumn{4}{|l|}{ Overall Experience } \\
\hline $\begin{array}{l}\text { The group project and the team must have } \\
\text { a clear objective to ensure that the group } \\
\text { tasks are structured in such a way that } \\
\text { students have identical learning objectives. }\end{array}$ & $\begin{array}{l}\text { The objective of the project was clearly discussed at the } \\
\text { beginning of the project and students were reminded of the } \\
\text { outcomes as the project progressed. }\end{array}$ & Yes & $\begin{array}{c}\text { Not } \\
\text { applicable }\end{array}$ \\
\hline $\begin{array}{l}\text { All group members should have an overall } \\
\text { positive experience. }\end{array}$ & Majority of respondents had an overall positive experience. & Yes & 6.1 \\
\hline \multicolumn{4}{|c|}{ Develop Understanding of Technical Subject-Specific Knowledge } \\
\hline $\begin{array}{l}\text { Students should learn about the content of } \\
\text { the task they were given to perform. }\end{array}$ & $\begin{array}{l}\text { Falls outside the scope of this article and is the subject under } \\
\text { consideration of another research study currently in progress } \\
\text { by Kruger and Rudman. }\end{array}$ & Not applicable & $\begin{array}{c}\text { Not } \\
\text { applicable }\end{array}$ \\
\hline \multicolumn{4}{|c|}{20} \\
\hline $\begin{array}{l}\text { Students should also learn more about } \\
\text { themselves, leadership, and providing } \\
\text { leadership. }\end{array}$ & $\begin{array}{l}\text { Majority of respondents indicated that one or more of the } \\
\text { group members accepted leadership of the project. }\end{array}$ & Yes & 6.2 .3 \\
\hline \multicolumn{4}{|l|}{ Project Management and Delegation } \\
\hline $\begin{array}{l}\text { Measures of performance should } \\
\text { encourage working as a group. }\end{array}$ & $\begin{array}{l}\text { A single mark was allocated to all members in the group. } \\
\text { There were instances where members felt they had to carry } \\
\text { other members. }\end{array}$ & Yes & 6.2 .4 \\
\hline $\begin{array}{l}\text { Students should be required to use project } \\
\text { management techniques, including } \\
\text { establishing deadlines, time management } \\
\text { tools, and scheduling tasks in a logical } \\
\text { manner. }\end{array}$ & $\begin{array}{l}\text { Various project management methodologies were used. } \\
\text { All projects were handed in on time; however, the students } \\
\text { indicated that the time available for the project was the } \\
\text { biggest obstacle in completing the project. }\end{array}$ & Yes & $6.2 .3 \& 6.3$ \\
\hline $\begin{array}{l}\text { Students should be responsible for } \\
\text { managing meetings effectively. }\end{array}$ & $\begin{array}{l}\text { Various methods were used to discuss material to include in } \\
\text { project. }\end{array}$ & Yes & 6.2 .3 \\
\hline $\begin{array}{l}\text { Tasks should be delegated in an effective } \\
\text { manner to ensure every member works } \\
\text { together. }\end{array}$ & Various methods were used to delegate work. & Yes & 6.2 .3 \\
\hline $\begin{array}{l}\text { An element of management and } \\
\text { supervision should be part of the group } \\
\text { project. }\end{array}$ & $\begin{array}{l}\text { Majority of respondents indicated that one or more of the } \\
\text { group members accepted leadership of the project. }\end{array}$ & Yes & 6.2 .3 \\
\hline \multicolumn{4}{|c|}{ Support and Collaboration with Other Students } \\
\hline $\begin{array}{l}\text { Heterogeneous groups } \\
\text { members with different and diverse } \\
\text { backgrounds and cultures should work } \\
\text { together and learn from others. }\end{array}$ & $\begin{array}{l}\text { Students were able to select their own group members. } \\
\text { Group for future projects will be selected to form a } \\
\text { heterogeneous group. }\end{array}$ & No & $\begin{array}{l}6.2 .1 ; 6.2 .2 \\
\quad \& 6.2 .4\end{array}$ \\
\hline $\begin{array}{l}\text { Group members should collaborate and } \\
\text { work together effectively and as a } \\
\text { consequence learn from each other. }\end{array}$ & $\begin{array}{l}\text { Majority of the students stated that they had learned from } \\
\text { other members and had learned new skills they would not } \\
\text { have learnt otherwise. }\end{array}$ & Yes & $\begin{array}{l}6.2 .3 ; 6.2 .4 \\
\quad \& 6.4\end{array}$ \\
\hline $\begin{array}{lccr}\begin{array}{l}\text { Students } \\
\text { interpersonal }\end{array} & \text { should } & \text { develop } & \text { both } \\
\text { competencies. } & & \text { and } & \text { group }\end{array}$ & $\begin{array}{l}\text { Majority of respondents indicated that they had learned non- } \\
\text { academic skills such as interpersonal skills and group } \\
\text { competencies. }\end{array}$ & Yes & $6.2 .4 \& 6.4$ \\
\hline $\begin{array}{l}\text { Students should learn about groups and } \\
\text { group dynamics. Project should include } \\
\text { scenarios which require students to resolve } \\
\text { conflict and negotiate appropriate } \\
\text { solutions and make changes to a group if } \\
\text { necessary. }\end{array}$ & $\begin{array}{l}\text { Majority of the respondents indicated that they had learned } \\
\text { how to resolve conflict and deal with different opinions and } \\
\text { had not required lecturer intervention. }\end{array}$ & Yes & 6.2 .3 \\
\hline \multicolumn{4}{|l|}{ Communication } \\
\hline $\begin{array}{l}\text { Project should encourage effective } \\
\text { communication in written and/or verbal } \\
\text { format. }\end{array}$ & $\begin{array}{l}\text { Falls outside the scope of this article and is the subject under } \\
\text { consideration of another research study currently in progress } \\
\text { by Kruger and Rudman. } \\
\text { Many of the students consulted with other students and the } \\
\text { project encouraged them to participate further in other classes. }\end{array}$ & Not applicable & $\begin{array}{c}\text { Not } \\
\text { applicable }\end{array}$ \\
\hline
\end{tabular}




\section{SUMMARY AND CONCLUSION}

This article reports on the results of a survey conducted to investigate the perceptions of students regarding the usefulness of a management accounting project in the form of a group work project to develop pervasive skills. The findings of the study confirm the findings obtained in other educational fields where group work is used. Key findings from Sawyer, Tomlinson, and Maples (2000) that pervasive competencies can only be developed in students if an interactive environment between students and real life is created within the classroom, was confirmed with students stating that they had developed new skills. It is apparent that students might be unaware of the skill requirements they need once they start working. Lectures should emphasise and explain to students at the beginning of project why it is important to learn group work skills at an early age. In this study, students indicated that the ability to work effectively in groups was a key skill students believed they had acquired during the project. They also indicated that they valued the exposure to a practical approach, thereby also confirming a key finding in the research conducted by Stainbank (2003). The management accounting group work project made a valuable contribution to students' studies, assisting them in developing the pervasive skills associated with group work in terms of leadership, delegation, effective communication, and support. The respondents agreed that the project was an appropriate method by which to teach pervasive skills. However, a number of students felt that it should not be extended to other subjects due to time constraints. The study showed that many students are not comfortable with working in groups. However, the feedback suggests that the more group work projects students engage in, the easier it will become in the long run. This is worth considering in the development of similar study aids.

In conclusion, the goals of the management accounting group work project were met by developing new skills. The respondents indicated that they thought incorporating group work as part of their studies was useful.

It is believed that this study has added a current understanding of issues faced by students participating in group work projects and that it should be of value in developing and implementing similar study aids in the South African context.

\section{AUTHOR INFORMATION}

Mr. Riaan Rudman is a Senior Lecturer at Stellenbosch University, South Africa. He lecturers at the under- and post-graduate levels. He obtained his Bachelors of Business Science (Finance Honours) degree as well as a Postgraduate Diploma in Accounting before qualifying as a Chartered Accountant (SA). He also holds two masters' degrees: a Masters of Business Science, in the field of finance and a Masters of Accountancy, awarded cum laude, in the specialist field of computer auditing. He specialised in Financial Institutions before joining academia. His areas of interest lie in business management and acceptable corporate behaviour in an electronic environment and new technologies. Mr. Riaan J. Rudman, Senior lecturer in Auditing and Information Systems \& Thuthuka Senior Project manager, BBusSc(Hons), PGDA, MBusSc, MAcc (cum laude), CA(SA). Tel.: +27 (21) 808 2701. E-mail: RJRudman@sun.ac.za (Corresponding author)

Mrs. Wandi Kruger is currently a lecturer in financial accounting, with previous experience lecturing information system at the Stellenbosch University, South Africa. She qualified as a Chartered Accountant, after graduating with BCompt Accounting Honours from the University of South Africa. After spending a few years working as an external auditor, she pursued a career as a lecturer at the Stellenbosch University where she obtained her Masters in computer auditing. Her interests lie in accounting education and teacher's education. Mrs. Wandi Kruger, Lecturer: Financial Accounting \& Information Systems, Stellenbosch University, South Africa. Tel.: +27 (21) 8082208. E-mail: WandivanRenen@sun.ac.za

\section{REFERENCES}

1. Ambrose, M. L., \& Kulik, C. T. (1999). Old friends, new faces: Motivation research in the 1990s. Journal of Management, 25(3), 231-293.

2. Anderson, R. (2005). The relationship between student perceptions of group dynamics and simulation game outcomes: An individual-level analysis. Journal of Education for Business, 81(2), 85-90. 
3. Ballantine, J., \& Larres, P. M. (2007). Final year accounting undergraduates' attitudes to group assessment and the role of learning logs. Accounting Education, 16(2), 163-183.

4. Barac, K. (2009) South African training officers' perceptions of the knowledge and skills requirements of entry-level trainee accountants. Meditari Accountancy Research, 17(2), 19-46.

5. Caldwell, M. B., Weishar, J., \& Glezen, G. W. (1996). The effect of cooperative learning on student perceptions of accounting in the principles course. Journal of Accounting Education, 14(1), 17-36.

6. Chartered Institute of Management Accountants (CIMA) (2010). Qualification structure and syllabus. CIMA Chartered Management Accounting Qualification 2010.

7. Coetzee, S., \& Oberholzer, R. (2009). The tax knowledge of South African trainee accountants: A survey of the perceptions of training officers in public practice. Accounting Education: An International Journal, 18(4-5), 421-441.

8. Cottell, Jr., P. G., \& Millis, B. J. (1993). Cooperative learning structures in the instruction of accounting. Issues in Accounting Education, 8(1), 40-58.

9. Dombrowski, R. F. (1993). Auditing students: A way to get meaningful practical experience. Issues in Accounting Education, 8(2), 320-334.

10. Edmondson, A., Bohmer, R., \& Pisano, G. (2001). Speeding up group learning. Retrieved from http://hbr.org/product/speeding-up-group-learning/an/R0109J-PDF-ENG

11. Gevers, J., \& Lubbe, I. (2012). Considerations for effective undergraduate group work design and implementation: Planning a financial reporting project. SAAA Western Cape Regional Conference, 7 September, Cape Town.

12. Gloeck, J. D., \& De Jager, H. (2000). The development of a common body of knowledge and skills for government auditors in South Africa. South African Journal of Accountability and Auditing Research, 3, $29-46$.

13. Gramling, A. A., Schatzberg, J. W., \& Wallace, W. A. (1996). The role of undergraduate auditing coursework in reducing the expectations gap. Issues in Accounting Education, 11(1), 131-161.

14. Hassall, T., Joyce, J., Arquero, J. L., \& Anes, J. A. D. (2003). The vocational skills gap for management accountants: The stakeholders' perspectives. Innovations in Education and Teaching International, 40(1), 78-88.

15. Holt, D. L., Michael, S. C., \& Godfrey, J. T. (1997). The case against cooperative learning. Issues in Accounting Education, 12(1), 191-193.

16. Hwang, G., Hwang, P. Y. C., \& Tsai, C. (2008). An enhanced genetic approach to composing cooperative learning groups for multiple grouping criteria. Educational Technology \& Society, 11(1), 148-167.

17. International Federation of Accountants (2006). Competence requirements for audit professionals IES 8. New York: International Federation of Accountants.

18. Jackling, B., \& De Lange, P. (2009). Do accounting graduates' skills meet the expectations of employers? A matter of convergence or divergence. Accounting Education, 18(4-5), 369-385.

19. Johnson, D. W., Johnson, R. T., \& Smith, K. A. (1992). Cooperative learning: Increasing college faculty instructional productivity. Retrieved from http://www.oid.ucla.edu/units/tatp/old/lounge/pedagogy/ downloads/cooperative-eric.pdf

20. Kaplan, R. S., \& Norton, D. P. (1992). The balanced scorecard - Measures that drive performance. Harvard Business Review.

21. Kennedy, F. A. (2000). Group performance: Using financial measures to evaluate the effect of support systems on group performance. (Ph.D. Dissertation). University of North Texas.

22. Knabb, M. T. (2000). Discovering group work: A novel cooperative learning activity to encourage group interdependence. The American Biology Teacher, 62(3), 211-213.

23. KPMG. (2009). Retrieved from http://www.kpmg.co.za

24. Lindquist, T. M., \& Abraham, R. J. (1996). Whitepeak corporation: A case analysis of a Jigsaw II application of cooperative learning. Accounting Education: A Journal of Theory, Practice and Research, 1, 113-125.

25. Lou, Y., Abrami, P. C., Spence, J. C., Poulsen, Chambers, B., \& D'Apollonia, S. (1996). Within-class grouping: A meta-analysis. Review of Educational Research, 66(4), 423-458.

26. Newcastle University (2009). Retrieved from http://www.ncl.ac.uk/nubs/undergrad/flyingstart/

27. O'Conner, D., \& Yballe, L. (2007). Group leadership: Critical steps to great projects. Journal of Management Education, 31(2), 292-312. 
28. Ohl, T., \& Cates, W. (2006). The nature of groups: Implications for learning design. Journal of Interactive Learning Research, 17(1), 71-89.

29. Peek, L. E., Winking, C., \& Peek, G. S. (1995). Cooperative learning activities: managerial accounting. Issues in Accounting Education, 10(1), 111-125.

30. Pescow, J. K. (1963). A visual approach to auditing and accounting instruction. The Accounting Review, 38(4), 839-843.

31. PricewaterhouseCoopers (PWC). (2009). Don't just think about it, do it! Retrieved from http://www.pwc.com/ZA

32. Ramsay, A., Hanlon, D., \& Smith D. (2000). The association between cognitive style and accounting students' preference for cooperative learning: An empirical investigation. Journal of Accounting Education, $18,215-228$.

33. Rassuli, A., \& Manzer, J. P. (2005). Teach us to learn: Multivariate analysis of perception of success in group learning. Journal of Education for Business, September/October, 21-27.

34. Rudman, R. J., \& Terblanche, J. (2012). The perceived advantage of work experience as a learning tool for university auditing students. Southern African Journal of Accountability and Auditing Research, 13, 57-71.

35. South African Institute for Chartered Accountants (SAICA). (2010). Competency framework. Detailed guidance for Academic Programmes. Retrieved from https://www.saica.co.za/Portals/0/LearnersStudents/ documents/INTEGRITAS-292277.pdf

36. Sawyer, A. J., Tomlinson, S. R., \& Maples, A. J. (2000). Developing essential skills through case study scenarios. Journal of Accounting Education, 18(3), 257-262.

37. Smith, J.vdL., \& Spindle, R. M. (2007). The impact of group formation in a cooperative learning environment. Journal of Accounting Education, 25, 153-167.

38. Stainbank, L. (2003). Using an annual report as a group project in accounting education. Meditari Accountancy Research, 11, 151-166.

39. Stainbank, L. J. (2009). Working in groups: improving the group experience. Meditari Accountancy Research, 17(1), 69-80.

40. Sullivan, E. J. (1996). Teaching financial statement analysis: a cooperative learning approach. Journal of Accounting Education, 14(1), 107-111.

41. Van Zyl, A. S. (2008). The impact of social networking 2.0 on organisations. The Electronic Library, 27(6), 906-918.

42. Vasarhelyi, M. A., Teeter, R. A., \& Krahel, J. P. (2010). Audit education and the real-time economy. Issues in Accounting Education. American Accounting Association, 25(3), 1-20.

43. Woodbine, G. (1997). Can the various forms of cooperative learning techniques be applied effectively in the classroom in content driven accounting courses? Retrieved from http://lsn.curtin.edu.au/tlf/tlf1997/ woodbine.html 
NOTES 